The Bangladesh Veterinarian (2015) 32 (1) : 19 - 26

\title{
Bacterial assessment of street-vended hog plum (Spondias mombin) and its public health importance
}

\author{
A Siddiqu, S Nasrin, M Moonmoon, MA Islam and MM Khatun* \\ Department of Microbiology and Hygiene, Faculty of Veterinary Science, Bangladesh \\ Agricultural University, Mymensingh-2202, Bangladesh
}

\begin{abstract}
To determine the microbial load of hog plum (Spondias mombin) (Local name Amra) sold by street vendors at Bangladesh Agricultural University (BAU) campus and Mymensingh city, samples of raw hog plum wash $(n=5)$, hand wash of vendors $(n=5)$, knife wash $(n=5)$ and stick wash $(n=5)$ were collected from five different hog plum vendors. Microbial quality of hog plums was assessed by total viable count (TVC), total coliform count (TCC) and total staphylococcal count (TSC). Samples were inoculated into Eosin Methylene Blue (EMB) agar, MacConkey agar and Mannitol Salt (MS) agar. Identification of Staphylococcus aureus and Escherichia coli (E. coli) were confirmed by sugar fermentation and biochemical tests. TVC ranged from $\log 6.9$ to $6.8 \mathrm{cfu} / \mathrm{mL}$ in raw hog plum wash, log 6.9 to $5.8 \mathrm{cfu} / \mathrm{mL}$ in vendors' hand wash, $\log 5.9$ to $4.9 \mathrm{cfu} / \mathrm{mL}$ in stick wash and $\log 5.3$ to $5.2 \mathrm{cfu} / \mathrm{mL}$ in knife wash samples. TCC of raw hog plum wash sample was log 3.4 to 2.3 $\mathrm{cfu} / \mathrm{mL}$ and in vendors' hand wash samples $\log 3.4$ to $1.3 \mathrm{cfu} / \mathrm{mL}$. TCC were not detected in stick and knife wash samples. TSC ranged from log 4.6 to $4.6 \mathrm{cfu} / \mathrm{mL}$ in raw hog plum wash, $\log 5.7$ to $4.6 \mathrm{cfu} / \mathrm{mL}$ in vendors' hand wash, $\log 4.6$ to $3.6 \mathrm{cfu} / \mathrm{mL}$ in stick wash and $\log 4.5$ to $4.5 \mathrm{cfu} / \mathrm{mL}$ in knife wash samples. Staphylococcus aureus were sensitive to ciprofloxacin, gentamicin and vancomycin and resistant to ampicillin and cephalexin. $E$. coli were sensitive to ciprofloxacin and gentamicin and resistant to ampicillin, penicillin $G$ and cephalexin. It is indicated that hog plum sold at BAU campus and Mymensingh city street harbour multidrug-resistant food-borne bacteria causing possible public health hazards. (Bangl. vet. 2015. Vol. 32, No. 1, 19 - 26)
\end{abstract}

\section{Introduction}

Hog plum (Spondias mombin) popularly called "Amra" is a well-known fruit in Bangladesh and is sold in open markets or streets. It is normally served as a flowerlike stick. People of all ages are fond off hog plum especially during summer (MarchSeptember). Hog plums are a rich source of vitamins, especially vitamin C (Akther et al., 2012). Hog plums are prone to microbial contamination because they are sold in open markets without covering. Street food vending has become an important public health issue. Major factors in microbial contamination are the place of preparation, utensils, raw materials, temperature and the personal hygiene of the vendor (Rane, 2011). The majority of street food vendors are ignorant of good hygiene practices (GHP: Mensah et al., 2002; Sultana et al., 2013), which increases the risk of contamination for food products (Bhaskar et al., 2004; Tambekar et al., 2009). Food-

*Corresponding author:- E-mail: minaramicro2003@yahoo.com. 
borne disease is commonly associated with Salmonella enteritidis (SE), Vibrio cholera, Escherichia coli serotype O157:H7 and Listeria monocytogenes (Mensah et al., 2002; Annan-Prah et al., 2011; Tambekar et al., 2011). Previous studies on hog plums have looked at their chemical composition, phytochemistry, pharmacology and pickle development (Bhuiyan, 2012). There are no reports on the bacteria in hog plum in Bangladesh. The objectives of this study were to identify bacteria in street-vended hog plum and to assess their antibiotic sensitivity.

\section{Materials and Methods}

\section{Collection of samples}

Samples of raw hog plum wash $(n=5)$, hand wash of vendors $(n=5)$, knife wash $(n=$ $5)$ and stick wash $(n=5)$ were collected from five places where vendors sell hog plum: BAU Library, KB High School, Botanical Garden, China Bridge-point and Station road, in Bangladesh Agricultural University (BAU) campus and Mymensingh city.

\section{Enumeration of total viable count (TVC)}

About $0.1 \mathrm{~mL}$ of each tenfold dilution was transferred and spread duplicate onto Plate count (PC) agar using micropipettes. The inoculated samples were spread on to the entire surface of the agar plate with a sterile glass spreader. One sterile spreader was used for each plate. The plates were kept in an incubator at $37^{\circ} \mathrm{C}$ for $24-48$ hours. After incubation, plates exhibiting 30-300 colonies were counted. The average number of colonies in each dilution was multiplied by the dilution to obtain the total viable count, as suggested by ISO (1995). The results were expressed as the number of Colony Forming Units (CFU) per gram of food samples.

\section{Enumeration of total coliform count (TCC)}

In case of coliform count, MacConkey agar was used. Protocols used in this method were similar to that of TVC.

\section{Enumeration of total staphylococcal count (TSC)}

In case of staphylococcal count, Mannitol salt agar was used. Protocols used in this method were similar to that of TVC.

\section{Isolation of bacteria}

Homogenized samples were enriched by overnight incubation in nutrient broth at $37^{\circ} \mathrm{C}$ for 24 hours. These were streaked in duplicate plates onto Mannitol salt agar (MSA) and Eosin Methylene Blue (EMB) agar and incubated at $37^{\circ} \mathrm{C}$ for 24 hours.

\section{Identification of bacteria}

Bacteria were identified by morphology of colonies, Gram's stain, sugar fermentation reaction, catalase, coagulase, Methyl Red (M-R), Voges-proskauer (V-P), and indole tests (Cheesbrough, 1985). 


\section{Antibiotic sensitivity test}

Antibiotic sensitivity was tested using 0.5 McFarland turbidity standard inoculum and freshly prepared, dried Mueller Hinton agar (Oxoid, UK) and six antibiotics: ampicillin, vancomycin, gentamicin, cephalexin, penicillin $G$ and ciprofloxacin. Two isolates of E. coli and S. aureus were selected randomly for the test. Disc diffusion or Kirby-Bauer method (Bauer et al., 1966) was used. The results were expressed as resistant, intermediate or sensitive according to the guidelines of Clinical and Laboratory Standards Institute (CLSI, 2007).

\section{Results and Discussion}

Total viable count (TVC), total coliform count (TCC) and total staphylococcal count (TSC) in raw hog plum wash samples

The highest TVC was from the China Bridge-point vendor $(\log 6.9 \pm 0.6 \mathrm{cfu} / \mathrm{mL})$ and the lowest in the Botanical garden vendor $(6.8 \pm 0.6 \mathrm{cfu} / \mathrm{mL})$.

The highest TCC was in the China bridge-point vendor $(\log 3.4 \pm 0.5 \mathrm{cfu} / \mathrm{mL})$ and the lowest in the BAU library vendor $(\log 2.3 \pm 0.5 \mathrm{cfu} / \mathrm{mL})$.

The highest TSC was in the China Bridge-point vendor $(\log 4.6 \pm 0.6 \mathrm{cfu} / \mathrm{mL})$ and the lowest in the BAU library vendor $(\log 4.6 \pm 0.5 \mathrm{cfu} / \mathrm{mL})$ (Table 1$)$.

Table 1: TVC, TCC and TSC in raw hog plum wash samples collected in different vending places

\begin{tabular}{c|l|c|c|c}
\hline $\begin{array}{c}\text { Name of } \\
\text { sample }\end{array}$ & Vending places & $\begin{array}{c}\text { TVC (mean log } \\
\mathrm{cfu} \pm \mathrm{sd} / \mathrm{mL})\end{array}$ & $\begin{array}{c}\text { TCC (mean log } \\
\mathrm{cfu} \pm \mathrm{sd} / \mathrm{mL})\end{array}$ & $\begin{array}{c}\text { TSC (mean log } \\
\mathrm{cfu} \pm \mathrm{sd} / \mathrm{mL})\end{array}$ \\
\hline $\begin{array}{l}\text { Raw hog } \\
\text { plum wash }\end{array}$ & $\begin{array}{l}\text { BAU Library, } \\
\text { Mymensingh }\end{array}$ & $6.8 \pm 0.6$ & $2.3 \pm 0.5$ & $4.6 \pm 0.5$ \\
& $\begin{array}{l}\text { KB High School, } \\
\text { Mymensingh } \\
\text { Botanical Garden, }\end{array}$ & $6.8 \pm 0.6$ & $2.4 \pm 0.6$ & $4.6 \pm 0.6$ \\
& $\begin{array}{l}\text { Mymensingh } \\
\text { China Bridge- point, }\end{array}$ & $6.8 \pm 0.6$ & $2.4 \pm 0.5$ & $4.6 \pm 0.6$ \\
& $\begin{array}{l}\text { Mymensingh } \\
\text { Station Road, } \\
\text { Mymensingh }\end{array}$ & $6.9 \pm 0.6$ & $3.4 \pm 0.5$ & $4.6 \pm 0.6$ \\
\hline
\end{tabular}

TVC: Total viable count; TCC: Total coliform count; TSC: Total staphylococcal count; cfu: Colony forming unit; sd: standard deviation

Total viable count (TVC), total coliform count (TCC) and total staphylococcal count (TSC) in vendor hand wash samples

The highest TCC was in the China Bridge-point vendor $(\log 6.9 \pm 0.6 \mathrm{cfu} / \mathrm{mL})$ and the lowest in the BAU Library vendor $(5.8 \pm 0.6 \mathrm{cfu} / \mathrm{mL})$. 
The highest TCC was in the China Bridge-point vendor $(\log 3.4 \pm 0.5 \mathrm{cfu} / \mathrm{mL})$ and the lowest in the BAU Library vendor $(\log 1.3 \pm 0.5 \mathrm{cfu} / \mathrm{mL})$.

The highest TSC was in the China Bridge-point vendor $(\log 5.7 \pm 0.6 \mathrm{cfu} / \mathrm{mL})$ and the lowest in the BAU Library vendor $(\log 4.6 \pm 0.6 \mathrm{cfu} / \mathrm{mL})$ (Table 2).

Table 2: TVC, TCC and TSC in vendor hand wash samples in different vending places

\begin{tabular}{l|l|c|c|c}
\hline $\begin{array}{c}\text { Name of } \\
\text { sample }\end{array}$ & Vending place & $\begin{array}{c}\text { TVC (mean log } \\
\mathrm{cfu} \pm \mathrm{sd} / \mathrm{mL})\end{array}$ & $\begin{array}{c}\text { TCC (mean log } \\
\mathrm{cfu} \pm \mathrm{sd} / \mathrm{mL})\end{array}$ & $\begin{array}{c}\text { TSC (mean log } \\
\mathrm{cfu} \pm \mathrm{sd} / \mathrm{mL})\end{array}$ \\
\hline $\begin{array}{l}\text { Vendor } \\
\text { hand wash }\end{array}$ & $\begin{array}{l}\text { BAU Library, } \\
\text { Mymensingh } \\
\text { KB High School, }\end{array}$ & $5.8 \pm 0.6$ & $1.3 \pm 0.5$ & $4.6 \pm 0.6$ \\
& $\begin{array}{l}\text { Mymensingh } \\
\text { Botanical Garden, } \\
\text { Mymensingh }\end{array}$ & $6.8 \pm 0.6$ & $2.37 \pm 0.52$ & $4.63 \pm 0.60$ \\
& $\begin{array}{l}\text { China Bridge-point, } \\
\text { Mymensingh }\end{array}$ & $6.9 \pm 0.6$ & $2.4 \pm 0.5$ & $4.6 \pm 0.6$ \\
& $\begin{array}{l}\text { Station Road, } \\
\text { Mymensingh }\end{array}$ & $6.9 \pm 0.6$ & $3.3 \pm 0.5$ & $5.7 \pm 0.6$ \\
\hline
\end{tabular}

TVC: Total viable count; TCC: Total coliform count; TSC: Total staphylococcal count; CFU: Colony forming unit; sd: Standard deviation

\section{Total viable count (TVC), total coliform count (TCC) and total staphylococcal count} (TSC) in stick wash samples

The highest TVC was found in the Station Road vendor $(\log 5.9 \pm 0.6 \mathrm{cfu} / \mathrm{mL})$ and the lowest in the Botanical Garden vendor $(4.8 \pm 0.6 \mathrm{cfu} / \mathrm{mL})$.

No coliforms were detected in stick wash samples.

The highest TSC was found in the Station Road vendor $(\log 4.6 \pm 0.7 \mathrm{cfu} / \mathrm{mL})$ and the lowest in the KB High School vendor $(\log 3.6 \pm 0.6 \mathrm{cfu} / \mathrm{mL})$ (Table 3).

Table 3: TVC, TCC and TSC in stick wash samples in different vending places

\begin{tabular}{c|l|c|c|c}
\hline $\begin{array}{c}\text { Name of } \\
\text { sample }\end{array}$ & \multicolumn{1}{|l|}{ Vending place } & $\begin{array}{c}\text { TVC }(\text { mean log } \\
\text { CFU } \pm \mathrm{SD} / \mathrm{mL})\end{array}$ & $\begin{array}{c}\text { TCC }(\mathrm{mean} \text { log } \\
\mathrm{CFU} \pm \mathrm{SD} / \mathrm{mL})\end{array}$ & $\begin{array}{c}\text { TSC (mean log } \\
\mathrm{CFU} \pm \mathrm{SD} / \mathrm{mL})\end{array}$ \\
\hline Stick wash & $\begin{array}{l}\text { BAU Library, } \\
\text { Mymensingh }\end{array}$ & $4.8 \pm 0.6$ & $\mathrm{ND}$ & $3.6 \pm 0.6$ \\
$\begin{array}{l}\text { KB High School, } \\
\text { Mymensingh }\end{array}$ & $4.8 \pm 0.6$ & $\mathrm{ND}$ & $3.6 \pm 0.6$ \\
$\begin{array}{l}\text { Botanical Garden, } \\
\text { Mymensingh } \\
\text { China Bridge-point, } \\
\text { Mymensingh } \\
\text { Station Road, } \\
\text { Mymensingh }\end{array}$ & $5.9 \pm 0.6$ & $\mathrm{ND}$ & $3.6 \pm 0.6$ \\
\hline
\end{tabular}

TVC: Total viable count, TCC: Total coliform count, TSC: Total staphylococcal count, cfu: Colony forming unit, sd: Standard deviation, ND: Not detected 
Total viable count (TVC), total coliform count (TCC) and total staphylococcal count (TSC) in knife wash samples

The highest TVC was in the China Bridge-point vendor $(\log 5.3 \pm 0.1 \mathrm{cfu} / \mathrm{mL})$ and the lowest in the Botanical Garden vendor $(\log 5.2 \pm 0.1 \mathrm{cfu} / \mathrm{mL})$.

No coliforms were detected in knife wash samples.

The highest TSC was found in the China Bridge-point vendor (log $4.5 \pm 0.6 \mathrm{cfu} / \mathrm{mL}$ ) and the lowest in the BAU Library vendor $(\log 4.5 \pm 0.5 \mathrm{cfu} / \mathrm{mL})$ (Table 4).

Table 4: TVC, TCC and TSC in knife wash samples in different vending places

\begin{tabular}{|c|c|c|c|c|}
\hline $\begin{array}{c}\text { Name of } \\
\text { sample }\end{array}$ & Vending place & $\begin{array}{l}\text { TVC (mean log } \\
\mathrm{CFU} \pm \mathrm{SD} / \mathrm{mL})\end{array}$ & $\begin{array}{l}\text { TCC (mean log } \\
\text { CFU } \pm \text { SD } / \mathrm{mL} \text { ) }\end{array}$ & $\begin{array}{l}\text { TSC (mean log } \\
\mathrm{CFU} \pm \mathrm{SD} / \mathrm{mL})\end{array}$ \\
\hline \multirow[t]{5}{*}{ Knife wash } & $\begin{array}{l}\text { BAU Library, } \\
\text { Mymensingh }\end{array}$ & $5.3 \pm 0.1$ & ND & $4.5 \pm 0.5$ \\
\hline & $\begin{array}{l}\text { K.B High School, } \\
\text { Mymensingh }\end{array}$ & $5.3 \pm 0.1$ & ND & $4.5 \pm 0.6$ \\
\hline & $\begin{array}{l}\text { Botanical Garden, } \\
\text { Mymensingh }\end{array}$ & $5.2 \pm 0.1$ & ND & $4.5 \pm 0.5$ \\
\hline & $\begin{array}{l}\text { China Bridge-point, } \\
\text { Mymensingh }\end{array}$ & $5.3 \pm 0.1$ & ND & $4.5 \pm 0.6$ \\
\hline & $\begin{array}{l}\text { Station Road, } \\
\text { Mymensingh }\end{array}$ & $5.3 \pm 0.2$ & ND & $4.5 \pm 0.6$ \\
\hline
\end{tabular}

TVC: Total viable count; TCC: Total coliform count; TSC: Total staphylococcal count; cfu: Colony forming unit; sd: Standard deviation, ND: Not detected.

In another study performed on various street foods in Dhaka city, Tabashsum et al. (2013) recorded average TVC values of the natural aerobic bacterial population ranging from $\log 3.0 \pm 0.0$ to $8.8 \pm 0.0 \mathrm{cfu} / \mathrm{g}$. The TVC in various street foods such as fried yam, fried potato, fried plantain and akara in the city of Lokoja, Nigeria, ranged from $5.0 \times 10^{4} \mathrm{cfu} / \mathrm{g}$ to $2.1 \times 10^{7} \mathrm{cfu} / \mathrm{g}$ (Madueke et al., 2014). The microbial load is relatively low in stick and knife wash used for preparing hog plums, but the hand wash and raw hog plum wash tend to accumulate higher microbial loads, suggesting poor hygiene.

Two bacterial species, namely Escherichia coli and Staphylococcus aureus were identified. Tambekar et al. (2011) isolated E. coli, S. aureus, Klebsiella spp. and Pseudomonas spp. from street-vended panipuri food. Saxena and Agarwal (2013) documented the presence of E. coli, S. aureus, Bacillus cereus, Shigella and Salmonella in street-vended Golgappa and Bhelpuri sold in Jaipur in Rajasthan, India. Adesetan et al. (2009) isolated S. aureus, E. coli, Bacillus subtilis from street-vended fruits in Ijebu area of Ogun state, Nigeria. The coagulase-positive character of Staphylococcus spp. indicated the presence of $S$. aureus species. The presence of $S$. aureus is a consequence of deficient hygiene of food handlers, since this bacterium contaminates food during 
handling or preparation. S. aureus is part of the normal flora of the human skin, respiratory tract, urethra, ear and mouth (Nwamaka et al., 2010). Its presence in food samples largely depends on inappropriate hygiene practices of the food handlers.

The isolation of coliform bacteria from hog-plum sample is indicative of faecal contamination. The presence of coliforms in the samples might be consequent to poor microbiological quality of the water used for washing fruits and utensils, as well as their storage at ambient temperatures in improper places, poor maintenance of the premises and lack of proper hygiene in vendors.

\section{Results of antibiotic sensitivity tests}

Two isolates - S. aureus and E. coli - were tested for antibiotic sensitivity. S. aureus was sensitive to gentamicin, ciprofloxacin and vancomycin and resistant to cephalexin and ampicillin. E. coli was sensitive to gentamicin and ciprofloxacin and resistant to cephalexin, ampicillin and penicillin G. Data suggests that hog plums sold by street vendors are contaminated with multidrug-resistant food-borne bacteria, which might pose a hazard to public health. The results of the antibiotic sensitivity test are presented in Fig. 1 and 2.

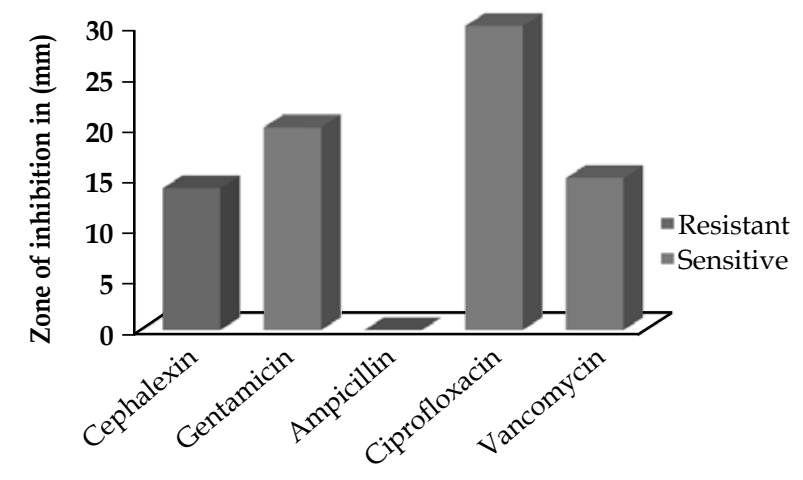

Fig. 1. Summary of antibiogram of Staphylococcus aureus using five antibiotics. Staphylococcus aureus was sensitive to three antibiotics and resistant to two.

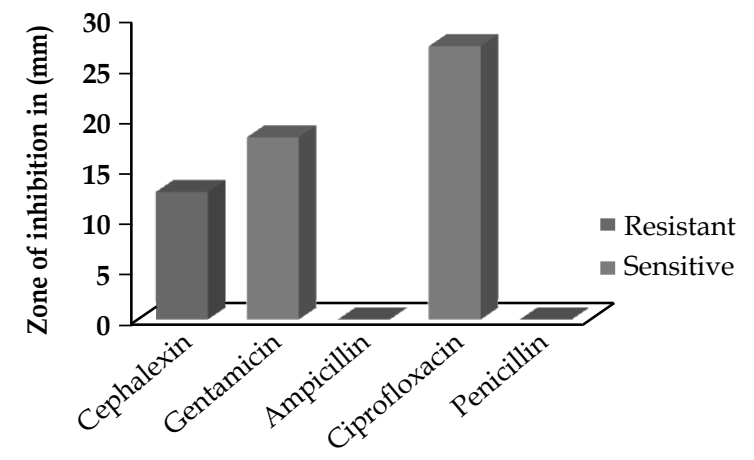

Fig. 2. Summary of antibiogram profile of E. coli using five antibiotics.

E. coli was sensitive to two antibiotics and resistant to three. 


\section{Conclusions}

The bacteria in hog plums showed multiple antibiotic resistances, which is a matter of concern for public health. The results underline the need for hygiene improvement and for increased awareness of sanitary practices during hog plum preparation and serving. Hygienic handling and health education are crucial for preventing spread of resistant bacteria and food poisoning through consumption of contaminated fruits.

\section{References}

Adesetan TO, Egberongbe HO, Ilusanya OAF, Bello OO 2009: Antimicrobial sensitivity of bacterial isolates from street vended fruits in Ijebu area of Ogun state, Nigeria. International Research Journal of Microbiology 4 220-225.

Akther S, Shahriar SMS, Akter F, Morshed S, Islam MN 2012: Study on chemical composition of fresh Mymensingh and Barishal hog plum (Spondias mangifera) and developed leather and jelly and sensory evaluation. Journal of Environmental Science and Natural Resources 5 29-36.

Annan-Prah A, Amewowor DHAK, Osei-Kofi J, Amoono SE, Akorli SY, Saka E, Ndadi HA 2011: Street foods: handling, hygiene and client expectations in a world heritage site town, Cape Coast, Ghana. African Journal of Microbiology Research 5 1629-1634.

Bauer AW, Kirby WMM, Sherris JC, Turck M 1966: Antibiotic susceptibility testing by a standardized single disc method. American Journal of Clinical Pathology 45 493-496.

Bhaskar J, Usman M, Smitha S, Bhat GK 2004: Bacteriological profile of street foods in Mangalore. Indian Journal of Medical Microbiology 22197.

Bhuiyan MHR 2012: Pickle and chutney development from fresh hog plum (Spondias dulcis). Journal of Environmental Science and Natural Resources 5 67-72.

Cheesbrough M 1985: Medical laboratory manual for tropical countries. $1^{\text {st }}$ edn. Microbiology. London: English Language Book Society; pp. 400-480.

Clinical and Laboratory Standards Institute (CLSI, formerly NCCLS) 2007: Performance standards for antimicrobial susceptibility testing. 17th Informational Supplement document M100-S17: 1. Wayne, Pennsylvania, USA. pp. 32-50.

ISO 1995: Recommendation of meeting of the subcommittee, International Organization for standardization on meat and meat products. Iso/tc 36 sc-6 The Netherlands pp. 10-18.

Madueke SN, Awe S, Jonah AI 2014: Microbiological analysis of street foods along LokojaAbuja Express Way, Lokoja. American Journal of Research Communication 2 196-211.

Mensah P, Manu DY, Darko KO, Ablordey A 2002: Street foods in Accra, Ghana: how safe are they? Bulletin of World Health Organization 80 546-554.

Nwamaka NT, Chike A, Obiajulu A 2010: Role of bacteria isolates in the spoilage of fermented African oil bean seed "ugba". Pakistan Journal of Biological Science 13 497-503. 
Rane S 2011: Street vended food in developing world: hazard analyses. Indian Journal of Microbiology 51 100-106.

Saxena G, Agarwal M 2013: Microbial quality assessment of street-vended Golgappa and Bhelpuri sold in Jaipur city of Rajasthan. International Journal of Food and Nutritional Sciences 2 71-77.

Sultana A, Awan A, Tehseen I 2013: Sanitation practices among food handlers working in street restaurants in Rawalpindi. Rawal Medical Journal 38 425-427.

Tabashsum Z, Khalil I, Uddin MN, Mollah AKMM, Inatsu Y, Bari ML 2013: Prevalence of foodborne pathogens and spoilage microorganisms and their drug resistant status in different street foods of Dhaka city. Journal of Agriculture, Food and Analytical Bacteriology 3 281-292.

Tambekar DH, Kulkarni RV, Shirsat SD, Bhadange DG 2011: Bacteriological quality of street vended food Panipuri: a case study of Amravati city India. Journal of Bioscience Discovery 2 350-354.

Tambekar DH, Murhekar SM, Dhanorkar DV, Gulhane PB, Dudhane MN 2009: Quality and safety of street vended fruit juices: a case study of Amravati city, India. Journal of Applied Biosciences 14 782-787. 